\title{
An Evaluation of the Major Implementation Problems of Primary School Curriculum in Cross River State, Nigeria
}

\author{
Grace Chikadibia Domike, Edward Ogar Odey* \\ Department of Curriculum and Teaching, University of Calabar, Calabar \\ *Corresponding author: edwardodey@yahoo.com
}

Received July 16, 2013; Revised November 07, 2013; Accepted June 09, 2014

\begin{abstract}
There is no gain saying the fact that effective implementation is very vital if the primary school curriculum is to achieve its goals of inculcating permanent literacy and numeracy, ability to communicate effectively, laying a sound basis for scientific and reflective thinking. Efforts of the federal government towards implementation of a sound curriculum for the schools have yielded little or no dividends due to issues which are inherent in the implementation of the primary school curriculum. These problems include under funding, ecology of the classroom, acute shortage of infrastructures, lack of health facilities, lack of qualified teachers, and neglect of the mother tongue, amongst others. This paper, therefore takes a critical look at the challenges of implementing the primary school curriculum in Cross River State. It was therefore recommended that the local government should be more aggressive in its implementation programs, government need for strategic planning, institutional capacity building and positive coordination of man and natural resources.
\end{abstract}

Keywords: evaluation, implementation, problem, primary school, curriculum

Cite This Article: Grace Chikadibia Domike, and Edward Ogar Odey, "An Evaluation of the Major Implementation Problems of Primary School Curriculum in Cross River State, Nigeria." American Journal of Educational Research, vol. 2, no. 6 (2014): 397-401. doi: 10.12691/education-2-6-12.

\section{Introduction}

Education has become one of the most powerful weapons known for reducing poverty and inequality in modern societies. It is also used for laying the foundation for a sustainable growth and development of any nation. Primary education is the core of development and progress in modern societies. It is the level of education that develops in the individual the capacity to read, write and calculate. In other words, it helps to eradicate illiteracy, which is one of the strongest predictors of poverty [8] Thus primary education is the only level of education that is available everywhere in both the developed and the developing countries as well as in urban and rural areas [5] This explains why primary education is the largest subsector of any education system and offers the unique opportunity to contribute to the transformation of societies through the education of young ones [21].

However, it is a truism that the new era in the history of primary education in Nigeria was opened in September 1976. when the then Head of State, and commander-inChief of the Armed force of Nigeria, Lt General Olusegun Obansanjo officially announced the Universal Primary Education (UPE) and declared that every Nigerian child should now regard basic education as his natural heritage, a right and no longer a privilege. This of course made primary education the sole responsibility of the Federal Government. According to [13] the aim was basically;

1. to wipe out illiteracy and evolve a uniform system of education through out the country.

2. to establish a wider base from which secondary schools could draw their entrants;

3. to increase manpower needs of the country

4. to increase the number of intake in primary schools.

Primary school became the base of Nigeria's educational system when the National Policy on Education system is built upon it. The primary level is therefore the key to the successes or failure of the whole system.

Therefore, in this work, effort was geared at taking a cursory look at the National Policy of Primary Education, primary school curriculum, and a critical analysis of the major implementation problems of the primary school curriculum in Cross River State suggestion and recommendations were also made.

\section{The National Policy on Primary Education}

An educational policy is a plan of action, statement of aims and ideas made by interdependent bodies, groups and individuals and aimed at achievement of educational goals [3]. [23] quoting Briggs noted that "education is a long 
term investment by the state to make itself a better place in which to live and a better place in which to make a living" in line with thought, the Federal Government recognized education as the weapon against ignorance, disease and poverty and a as a mean of raising enlightened, lively and industrious citizenry and producing a prosperous nation (Ugwu, 1998). It was in an attempt to actualize this that the Federal Government amongst all other efforts articulated policies as found in the National Policy on education which have a far reaching effect on all levels of education.

Therefore, section 3 of the [13] deals especially with primary education which it describes as that part of education given to children between the ages of 6 to $11+$. It recognizes the fact that primary education is the key to success or failure of the entire education system. Attaching importance to this level of education, the policy outlined the following general objectives for primary education in all the states of the federation:

a. the inculcation of permanent literacy and numeracy and the ability to communicate effectively;

b. the laying of sound bases for scientific and reflective thinking;

c. citizenship education for effective participation and contribution in the society;

d. character and moral training;

e. developing in a child the ability to his environment

f. providing opportunities for the development of manipulative skills and;

g. providing basic tools for further educational advancement (p14).

Aside these general objectives, there are some policy statements on how its implementations should be facilitated. These amongst other things are;

- The following educational services shall be provided:

I. School library;

II. Basic health scheme;

III. Counselling;

IV. Educational resource centre;

V. Specialist teachers of particular subjects such as mathematics, science, physical education, language arts (in relation to English, French, sign language and Nigerian languages), librarian, music, fine art and home economics.

- Teaching shall be practical, explanatory and experimental methods.

- The medium of instruction in the primary school shall be the language of the environment for the first three years. During this period, English shall be taught as a subject.

- From the fourth year, English shall progressively be used as a medium of instruction and the language of immediate environment and French shall be taught as subjects.

- For effective teaching and learning the teacher pupil ratio shall be 1:35

- Advancement from one class to another shall be based on continuous assessment.

- The primary school leaving certificate shall be based only on continuous assessment and shall be issued locally by the head teacher of the school.

- with view to correcting the imbalance between different parts of the country, with reference to the availability of educational facilities and the number of pupils receiving formal education and girls education:

- State government shall ensure the integration of formal basic education curriculum into koranic and islamiya schools;

- Special efforts shall be made by appropriate agencies to encourage parents to send their daughters to school.

- Everything possible shall be done to discourage the incidence of dropping out of the primary level of education. However, if this occurs, provision shall be made in the context of adult and non-formal education to enable such early leavers to continue with their education.

- Government welcomes the contributions of voluntary agencies, communities and private individuals in the establishment and management of primary schools alongside those provided by the state and local governments as long as the meet the minimum standards laid by the federal government.

- In recognition of the prominent role of information and communication technology in advancing knowledge and skills necessary for effective functioning in the modern world. There is urgent need to integrate information and communication technology (ICT) into education in Nigeria.

Government shall therefore provide basic infrastructure and training for the realisation of this goal at the primary school level (pp 15-17).

\section{The Primary School Curriculum Modules}

According to [17] curriculum is the summation of systematically planned process of teaching and learning based on the aims and objectives of the educational policy of any country. It is made up of academic or subject based curriculum and non academic or extra curriculum programmes. The primary schools curriculum module is an academic curriculum based on all subjects designed for the primary school level.

According to [24] curriculum is a human educational enterprise in which people attempt to do something in a purposeful thoughtful and careful way. Acting purposefully with some and or procedure in mind in one sense at least, holding that end or procedure as valuable, good and desirable.

However, [17] opined that the current primary school curriculum is the result of Sofolahan committee write-up held in 1987. In a well simplified form and term in the different subjects, the curriculum modules are programmed schemes-of-work based on the national syllabus for primary schools. Discussions are based under the following headings; the primary schools curriculum Modules (1998).

a) the number of the module;

b) the topic, content or subject matter dealt with in the module;

c) Content elements: that is, a breakdown of the content into small separate units of the subject matter. This enables the teachers to deal with the topics in small steps; 
d) objectives; that is knowledge to be gained or the skills to be acquired by pupils after the teaching/learning interplay on the module; these are stated in behavioural terms or changes in behaviour expected of the pupils.

e) Pupils activities that will lead to the objectives by performing these activities, pupils will be able to gain the knowledge or acquire the skills stated in the objectives.

f) Teaching aids and teachers' hints are suggested to assist teachers in the preparation of their lessons,

g) Suggested assessment techniques on the instrument to be used for assessment;

h) The period of time work in the module is expected to last is stated in weeks (P.2).

\section{The Implementation Problems of the Primary School Curriculum in Cross River State; A Critique}

There is no gainsaying that the Nigerian government has good intention to fulfill primary education purpose as stated in the National Policy on Education. But she has failed in achieving the intended objectives. As good as primary education is in providing the basic skills needed to acquire permanent literacy and numeracy as well as to gain admission into secondary schools, Nigerian primary schools are not fulfilling the central purpose of primary education. Before Nigeria's attainment of independence, primary schools were effectively managed by the missionaries and voluntary agencies with grant-in-aid from colonial government [10].

However, the management of primary education system by the Nigerians has experienced serious problems. The introduction of Universal Primary Education (UPE) nationwide in 1976 experienced problems of underestimation of about 30 percent of the turn-up number of the children enrolment, acute shortage of classroom spaces, shortage of teachers and equipment. This has indicated that primary school education is under-funded; most of the primary sections controlled and financed by the government are in shamble [4] This may not be unconnected with the neglect and lack of maintenance as a result of poor economic depression. In the northern senatorial district of Cross River State, primary schools existing in the remote areas like Ebo, Wanokom Yahe, Ukelle, Ntrigon are nothing to write home about as the pupils attend their classes in open roof building. The inability of the government to effectively run primary schools has made people to agitate for the return of schools to the missionaries and other voluntary agencies.

In line with the above, [16] asserts that, for teaching and learning to go on smoothly, factors other than teachers and the pupil play significant role. The ecology of the classroom cannot therefore be overemphasized. Ecology of the classroom according to Nwaogu refers to the environment of people, that is, the curriculum, actual teaching, classroom management, classroom climate (noisy or quite) and the physical condition of the classroom (dark or ventilated, hard floor, arrangement of seats, etc.)

Conversely, many primary schools in Cross River State are experiencing acute shortage of infrastructures, nonpayment of teachers' salaries and security problems. Some primary schools have not enough classrooms and furniture to the extent that classes are held under shades of trees, some pupils carry-homes their branches and desks and bring term to school every morning. The instructional materials needed to aid teaching-learning activities are not available. The teachers are no longer committed to their jobs because they are not well paid. It is obvious that unless these teachers are provided with the drive that would energize them or the tools needed, that is proper inputs, their best could not be tapped or attained and the accomplishment of educational goals would be difficult. [8].

In furtherance to these, [16] postulated that many primary schools especially those located in rural areas have no access to health facilities. Hospitals and health centres are not within walking distances. Within the school themselves, there are no first aid boxes and trained personal to offer pupils emergency relief in cases of minor problems.

Moreover, it is a truism that in realization of the fact that unequal access to educational opportunity is one of the strongest correlates of socials inequality, the federal government has embarked on a massive expansion of access to primary education. The 1976 UPE and the UBE programmes were aimed at making basic education accessible to all children of schools age irrespective of their social, economic, culture or geographical backgrounds. As one should expect, there has been a corresponding expansion of secondary and tertiary education including teacher's education in Nigeria [5]. However, the quality of primary education has not kept abreast of the expansion in enrolment in Cross River State. Although, this according to [21] continues to be a global concern, yet it is the general belief that the competence of the teacher is central to the education of children. In a way therefore, what constitute competence in teaching is intimately connected with the type of teacher education programmes available for preparing primary teachers. Therefore, one of the problems of implementing the primary school curriculum in Cross River State is the poor quality of teachers produced from teachers; colleges [20].

In line with the above, [4] attributed the poor quality of products of colleges of education among other things to the quality of students admitted into the colleges. According to [4] the lowering of the admission requirement for whatever reasons, has not only affected the quality of the products of the colleges but also the image, student teachers do not find prestige in the teaching profession thereby hindering the effective implementation of the primary school curriculum. [4] position is in consonance with [14], [2] and [11] who in their various studies observed that lack of qualified primary school teachers is the major cause of the poor turn out of primarily school pupils.

More so, it is worthy of note that the national Policy on education prescribes that the teacher-pupil ratio should be 1.35. In Cross River State, the classrooms are overcrowded and in some instances schools have operated with teacher-pupil ratio of 1.76. A programme for classroom building, to support the implementation of a scheme for Universal Primary Education was either never developed or if it was, it was not successfully implemented [15].

Moreover, poor funding could also be seen as another factor that has bedeviled the implementation of the 
primary school curriculum in Cross River State. According to [10], the history of primary education administration as viewed reveals the instability in the government commitment to the financing of primary education. Apart from different legislature on education in form of ordinances that were enacted, joint responsibility of regions and federal government on education started in the Macpherson constitution of 1951. There is no gainsaying that despite the increase in the number of primary schools and government commitment in the funding of this level of education when the UPE was introduced by both the Regional and Federal Government between 1955 and 1976, there has been inadequate funding and poor management. The situation was not far from the same during the take over of the ownership and management of all primary schools, the takeover of financing by the federal government in 1976 and during the transfer of funding to the state and local government in 1979 [1].

In 1988, National Primary Education Commission (NEPC) was establishment with Decree 31 of Federal Republic of Nigeria and there was the emergence of the national education fund to allocate fund to State Primary School Education Board of all states of the federation and other agencies responsible for federal government sponsored special primary education project. Instead of deducting the fund needed for primary education administration directly from the federal government accounts there was a separate fund. The establishment of this fund has no doubt brought lapses in financing of primary education in Nigeria (Cross River State inclusive). [7] opined that the federal government proportion of budget and recurrent allocation fall from $21 \%$ to $13 \%$ in 1988 and a total capital allocation from $7 \%$ to $4 \%$ over the same period.

According to [25], there was a progressive withdrawal of Federal Government financing of primary education through the early and mid 1980s. Since these periods, primary school level has been under serious financial pressure and unstable government till date. There is an inadequate supply of human and materials resources, overcrowded classrooms in urban school, poor maintenance, poor supervision and poor learning environment. Presently in Cross River State it seems as if the primary school level is floating, not sure of where they belong, its teachers do not know their employer: (federal, state or local government). Though its administration is being controlled by the State Universal Basic Education Board (SUBEB) the funding is the responsibility of the federal, state and local governments. This without any doubt affects the inputs and outputs of the system adversely.

In addition, [18] postulated that the neglect of the mother tongue in the curriculum is a serious wrong and it makes learning difficult and uninteresting to the pupils. There is no doubt that the mother tongue provides the sweet key to the child's mind as he gains the experience of his immediate surrounding through the same language. It logically follows according to [9] that all meaningful education of the child ought to proceed from it because it is the language in which he moves and has his being. In addition, one should remember that a foreign language inherited from an important power has the stigma of colonial mentality attached to it. It therefore follows that the Nigeria primary education system to be meaningful and culturally oriented, it must use the Nigerian language in some instructions. In Cross River State, Local language(s) is hardly taught in schools even where there exists a provision for such; there is lack of qualified teachers to do that.

More so, the present Nigerian primary School curriculum has not much to do with everyday life of a child. The subjects are taught from a point of view which is both foreign and strange to the child's experience. Besides, too much emphasis is placed on examination. This strangles the curriculum and makes what does not directly pertain to the examination seen unimportant and unnecessary. Such is detrimental to the general acquisition of knowledge by the pupils [18] From the sampled schools in the three (3) education zones in Cross river State as presented in Table 1 below, it is obvious that there has been poor implementation of the primary school curriculum.

Table 1. THE IMPLEMENTATION OF PRIMARY SCHOOL CURRICULUM AND CROSS RIVER STATE

\begin{tabular}{|c|c|c|c|c|c|c|c|c|c|c|}
\hline \multirow[t]{2}{*}{$\begin{array}{l}\text { Education } \\
\text { zones. }\end{array}$} & \multirow[t]{2}{*}{$\begin{array}{l}\text { No. of schools } \\
\text { Sampled }\end{array}$} & \multicolumn{4}{|c|}{ Quality of staff } & \multirow[t]{2}{*}{$\begin{array}{l}\text { Classroom } \\
\text { space }\end{array}$} & \multirow[t]{2}{*}{$\begin{array}{l}\text { Teacher } \\
\text { pupil ratio }\end{array}$} & \multirow[t]{2}{*}{$\begin{array}{l}\text { Health } \\
\text { facilities }\end{array}$} & \multirow[t]{2}{*}{$\begin{array}{l}\text { Language } \\
\text { used. }\end{array}$} & \multirow[t]{2}{*}{ Funding } \\
\hline & & B.Ed & Dip & NCE & WASC/GCE & & & & & \\
\hline $\begin{array}{l}\text { Calabar } \\
\text { Education zone }\end{array}$ & 10 & - & - & 20 & 36 & Inadequate & $1: 50$ & Inadequate & $\begin{array}{l}\text { English } \\
\text { Language }\end{array}$ & Poor \\
\hline $\begin{array}{l}\text { Ikom Education } \\
\text { zone }\end{array}$ & 10 & 2 & 3 & 7 & 11 & Inadequate & $1: 45$ & Inadequate & $\begin{array}{l}\text { English } \\
\text { Language }\end{array}$ & Poor \\
\hline $\begin{array}{l}\text { Ogoja } \\
\text { Education zone }\end{array}$ & 10 & - & 7 & 4 & 15 & inadequate & $1: 76$ & Nil & $\begin{array}{l}\text { English } \\
\text { Language }\end{array}$ & Poor \\
\hline
\end{tabular}

Source: Authors surveyed field work of sampled schools in the Education zones of Cross River State.

The system has also created and favoured disunity in

the country. It emphasizes memory learning rather than thinking, imitation rather than originally and conformity rather than initiative. This is detrimental to a developing country. The Nigerian primary school system should foster Nigerian language, dresses, songs, dances and cultural heritage. Any educational system that undermines the significance and importance of the traditional background is not good enough for Nigeria. Education in Japan is Japanese, education in Russia is Russian. Education in America is American. But one tempted to ask what education is in Nigeria? The answer of course is not far-fetched British- American.

\subsection{Conclusion}

The achievement of the objective of any programme depends largely on the management of available human and materials resources. The achievement of the primary education objectives in Nigeria depends on the adequate implementation of the primary school curriculum modules which depends on provision of basic facilities and positive supervision of teachers and other school personnel. The UBE may be a mere political point and not educational achievement. 


\subsection{Recommendation}

- Education is the vital instrument for socials and education mobility at the personal level and as instrument for transformation of the society at the national level. Primary education is a foundational level of education that needs to be well funded, controlled and managed. Without mincing words, the management of primary education by the local government is a very big task that needs serious commitment before much could be achieved. The control and management of primary school education in Nigeria should be the joint responsibility of both federal and local government. The local government should be involved because it is the government closer to the grassroots with less responsibility on education administration.

- It is the government failure to provide qualitative education as a result of poor management and funding that necessitates increased private ownership of primary education system in Nigeria. The intervention of federal government is needed to secure public primary schools which are the hope of the poor in giving education to their children, from total collapse.

- To successfully implement the UBE Scheme, there is need to develop sound implementation plans. This would have to be preceded by a survey of the existing resources and capacity of the national and local planning structures to implement the plan and monitor progress made in order to detect problem areas and address them at early stage.

- More so, strategic planning and implementation are essential to the success of the nine (9) year programme and for capacity building in the system, as well as its implementation. Failure in the past cannot be blamed entirely on low levels of funding but also on lack of capacity for planning and implementation at both nationals and local levels. National structure such as the planning division of the Federal Ministry of Education would need to be strengthened to ensure that there is capacity in those structures to monitor implementation plan on the system. The present effort of the Federal Ministry of Education in collaboration with both UNESCO and UNDP on the creation of Education Data Bank is highly commendable [12].

- There is also the need to set up an institutional capacity building. The school managers should be mandated to attend training workshops and conferences to improve management skills. Effort should also be made to promote gender balance in schools.

- The achievement of the curriculum objectives demands positive coordination of man and material resources through effective supervision. Effective supervisory practice is therefore needed if a teacher in service programme is to be beneficial to all concerned. There should also be an establishment of co-operative curriculum study and development units in schools. Planning-in-service programme such as sandwich Long Distance Learning and Weakened programs for teachers should also be encouraged.
Regular inspections of primary schools to confirm regulation in curriculum implementation should also be encouraged.

\section{References}

[1] Abdulkareem, A. Y. (1997). Follow-up study on primary Education Cost, Financing aManagement in Kogi, Kwara and Niger States and the FCT. National PrimaryEducation Commission Project.

[2] Adeleke, T. O. (2001). Student Teachers' Perception and Attitude towards Teaching in the primary School. B.Ed Thesis, University of Ibadan.

[3] Adetoro, E. J. (1966). Handbook on Education in Nigeria; Ibadan: African Education press.

[4] Akinbote O. (2000). Problems of Poor Quality in Primary School Teachers Preparation: A study of Nigeria's College of Education. African Journal of Education planning and policy Studies 1(1) 3339.

[5] Akinbote O. (2001). The Nigerian Primary School Teachers: Angels of Instruction or devils of destruction? Ibadan: Ibadan University Press.

[6] Akinbote O. (2007). Problems of Teachers Education for Primary Schools in Nigeria: Beyond Curriculum Design and Implementation. Ibadan: Ibadan University Press.

[7] Babalola, J. B. (1996). Proliferation of private schools in Nigeria. In A. O. Ajaji and I. A. Akinwumiju (Eds) Personnel Performance and Capacity Building. Department Educational Management, University of Ibadan.

[8] Bruns, B., Mingart, A \& Rakotomalal, R. (2003). Achieving Universal Primary Education by 2015: A chance for every child. Washington D. C. The World Bank.

[9] Enobakhare, G. N. I (1971). How shall we Educate Nigeria. London Macmillian.

[10] Olaniyan, D. A. \& Obadara, E. O. (2004). A Critical Review of management of primary Education in Nigeria. Ibadan: university of Ibadan Press.

[11] Durosaro, D. O. (2006). Critical issues in the management of primary Education in Nigeria. Illorin: University of Illorin.

[12] FGN/UNESCO/UNDP (2003). A Decade of Basic Education Data in Nigeria (1988-1998).

[13] Federal Republic of Nigeria (2004). National Policy on Education ( $4^{\text {th }}$ ed.) Lagos NERDC Press.

[14] Liberman, M. (1956), Education as a Profession. New Jersey: Prentice Hall.

[15] Moja, T. (2000). Nigeria Education Sector Analysis: an analytical synthesis of performance and main issues. New York: World Bank.

[16] Nwaogu, P. (1990). Factors which influence Teaching and learning in Nigerian primary schools. In Maduewesi, E, J. (ed) General methodology for primary schools. Awka: African Fep publishers Ltd.

[17] Oghuvbu, E. P. (2011). Implementation of the primary school Curriculum Modules in Niger: the role of supervision Abraka: Kamla- Ray Anththropologist 13 (2)147-150.

[18] Onah, J. N. (1998). Problems and prospect of primary Education in Nigeria. In A. B. C. Ugwa, (Ed.) Introduction to Primary Education Studies. Enugu: Dona prints Ltd.

[19] Sofolahan. J A. O. (1987). National Workshop on Continuous Assessment in Primary Schools and writing of National Curriculum Modules held in Port Harcourt.

[20] Taiwo, C. O. (1982). The Nigerian Education System: Past present and Future. Ikeja Thomas Nelson Nigeria Ltd.

[21] UNESCO (2001). Primary Education: The core of Development and progress. UNESCO Education Webmaster.

[22] Ugwu, J. C. (1998). Understanding Philosophy of Education. Enugu: Calvaside Printing and Pub. Co.

[23] Ukeje, B. O. (1992). Educational Administration. Enugu: Fourth Dimension Pub. Ltd.

[24] Urevbu, A. (1990). Curriculum Studies. Lagos Longman Pub.

[25] World Bank (2003). School Education in Nigeria: Preparing for Universal Basic Education, (Human Development II, African Region). 